Bored, Lonely, Angry, Stupid 



\section{Bored, Lonely, Angry, Stupid}

Changing Feelings about Technology, from the Telegraph to Twitter

Luke Fernandez

Susan J. Matt

II Harvard University Press

Cambridge, Massachusetts, and London, England 2019 
Copyright ( $) 2019$ by the President and Fellows of Harvard College All rights reserved

Printed in the United States of America

First printing

Jacket design: Tim Jones

9780674239371 (EPUB)

9780674239388 (MOBI)

9780674239364 (PDF)

The Library of Congress has cataloged the printed edition as follows:

Names: Fernandez, Luke. | Matt, Susan J. (Susan Jipson), 1967- author.

Title: Bored, lonely, angry, stupid : changing feelings about technology, from the telegraph to Twitter / Luke Fernandez and Susan J. Matt.

Description: Cambridge, Massachusetts : Harvard University Press, 2019. | Includes bibliographical references and index.

Identifiers: LCCN 2018043580 | ISBN 9780674983700 (alk. paper)

Subjects: LCSH: Technology-Social aspects-United States. Technology-United States-Psychological aspects. | Technological innovations-Social aspects-United States. | Technological innovations-United States-Psychological aspects.

Classification: LCC T14.5 .F385 2019 | DDC 303.48/30973-dc23

LC record available at https://lccn.loc.gov/2018043580 


\section{For Our Parents}

James and Renate Fernandez

Joseph (1920-2007) and Barbara Matt

who taught us the joys and virtues of collaboration 
